\title{
Zika; A Threat to Making Important Decisions on Maternal and Perinatal Health
}

\author{
Reynoso Vázquez Josefina ${ }^{1}$, Ruvalcaba Ledezma Jesús Carlos ${ }^{2 *}$, Chavarría Miranda \\ Alejandra ${ }^{3}$, Jiménez Sánchez Reyna Cristina ${ }^{4}$, Guzmán Meneses Karla Patricia ${ }^{5}$ and \\ Alamilla Pérez Karina ${ }^{5}$
}

\begin{abstract}
${ }^{1}$ Department of Pharmacy and Master in Public Health [ICSa-UAEH] Institute of Health Sciences-Autonomous University of the State of Hidalgo, Pachuca, Mexico. ${ }^{2}$ Department of Medicine, Master in Public Health and PhD. In Foods Sciences an Human Health in [ICSa-UAEH]. ${ }^{3}$ Department of Public Health [Instituto Elise Freinet] and [SSH] Health Services of Hidalgo, Pachuca, Mexico. ${ }^{4}$ Department of Nursing in [ICSa-UAEH]. ${ }^{5}$ Students of the Bachelor of Pharmacy At [Uaeh].
\end{abstract}

\begin{abstract}
The Zika virus disease represents a great challenge for the medical-scientific community not only because of the association that exists with microcephaly and other congenital anomalies, but also because of the presence of confirmed cases of congenital syndrome associated with Zika in asymptomatic pregnant women, It is very important to carry out a timely detection and diagnosis to evaluate the probability of having an anomaly, the quality of life that the baby will have or the probability of the legal interruption of pregnancy.
\end{abstract}

Keywords: Zika, Association, Microcephaly, Asymptomatic.

\footnotetext{
*Correspondence: dcspjcarlos@gmail.com, (771) 1327538 ext. 4311, 5548817657. ICSA. Ex Inland revenue La Concepción, n / n; Pachuca-Actopan Highway, Tilcuautla Highway. Pachuca Hidalgo, Mexico.

(Received: 03 October 2018; accepted: 17 November 2018)

Citation: Reynoso Vázquez Josefina, Ruvalcaba Ledezma Jesús Carlos, Chavarría Miranda Alejandra, Cristina Guzmán Meneses Karla Patricia, Alamilla Pérez Karina, Zika; A Threat to Making Important Decisions on Maternal and Perinatal Health, J Pure Appl Microbiol., 2019; Vol. 13(1):45-49 doi: 10.22207/JPAM.13.1.04

(C) The Author(s) 2019. Open Access. This article is distributed under the terms of the Creative Commons Attribution 4.0 International License which permits unrestricted use, sharing, distribution, and reproduction in any medium, provided you give appropriate credit to the original author(s) and the source, provide a link to the Creative Commons license, and indicate if changes were made.
} 


\section{INTRODUCTION}

The term Zika means "covered" in the Luganda language, also known as Ganda, it is a Bantu language that is spoken mainly in the region of Uganda ${ }^{1}$, This disease was identified for the first time in the Zika forest of Uganda in Africa during the year 1947, in a Rhesus monkey during a Yellow Fever transmission investigation and until 1952 in humans in Uganda and Tanzania; 2 , isolating the virus and thus demonstrating its transmission through the bite of the infected vector mosquito (only female mosquitoes bite), blood transfusions or their derivatives, from mother to child, particularly during the last week of pregnancy and new studies reveal the possible sexual transmission. ${ }^{3}$

As of 2007, they began to detect cases in humans outside Africa in an outbreak in the Islands of Micronesia, later in the French Polynesia Islands (2013-2014) and in Brazil during 2015

Aedes (aegypti and albopictus) mosquitoes have been identified as the main vector, however, it has been shown that Anopheles, Culex and others can also act as vectors, even with greater spreading potential than the Zika virus in America; likewise, typical species of these regions, such as those of the genus Haemagogus and Mansonia, could act in the same way as vectors. ${ }^{5}$

The Zika viral disease is caused by a flavivirus, it is estimated that $80 \%$ of patients are asymptomatic or oligosymptomatic, however the most common clinical picture is the presence of macular or papular rash, fever, arthritis or arthralgia, non-purulent conjunctivitis, myalgia, headache, retro-orbital pain, edema and vomiting, other symptoms associated with acute infection are, although less frequent, hematospermia, hand and ankle edema and subcutaneous hemorrhage, the disease is usually mild and lasts up to 1 week. ${ }^{6}$ So far there is no existing vaccine and the treatment is aimed at patients' clinical management and support, however in pregnant women the use of Hydroxychloroquine (HCQ) could reduce the effects caused by the Zika virus on the fetus according to new studies conducted in the USA, which have shown their antiviral effects on flaviviruses in animals?

After the recognition of the Zika virus transmission on September 2015 and the increase in the number of children with microcephaly in
Brazil, multiple studies and tests were carried out to demonstrate the association between the Zika virus infection and microcephaly, being the experts, researchers, very careful when publishing their results because the studies did not have sufficient evidence to demonstrate causality. ${ }^{7}$ These studies have documented the finding of the virus in brain and placental tissue of newborns and fetuses whose mothers had presented signs of the Zika infection during her pregnancy. ${ }^{8}$ In Mexico on October 2015, the first autochthonous case of the Zika virus infection was identified, and from that month on in 2015 to August 6, 2018 a total of 12,027 cases have been confirmed, with transmission in 28 states, of which 7,021 correspond to pregnant women. $9,{ }^{10}$ Of the total of pregnant women in Mexico, 40 cases of congenital syndrome associated with Zika virus have been reported, with microcephaly ( 28 cases) as the main affectation of the 5 that this syndrome includes, also reported cases with the presence of anencephaly ( 3 cases), hydrocephalus (1 case), craniosynostosis (1 case), macrocephaly ( 2 cases), microcephaly + ventriculomegaly ( 3 cases), microcephaly + hydrocephalus + clubfoot (1 case) and microcephaly + congenital heart disease + bilateral ventriculomegaly ( 1 case), all the previous ones had a mortality rate of $22.5 \% .10$ In 7.5\% of confirmed cases of congenital syndrome associated with Zika in Mexico were asymptomatic, $17.5 \%$ of women presented infection during the second trimester of pregnancy and $75 \%$ of women had the infection in the first trimester of pregnancy. ${ }^{10}$

\section{Confirmed cases of Congenital Syndrome associated with Zika in the state of Hidalgo}

In Hidalgo the first autochthonous case was recorded in 2016, confirming that by the end of that year with 191 more cases, of which 164 corresponded to pregnant women, in 2017 a total of 85 cases were confirmed, 17 being pregnant and by 2018 , up to August 6,8 cases were confirmed, there were no pregnant women reported. Of the cases in pregnant women in Hidalgo, only 2 cases have been confirmed, both during the first trimester of pregnancy, one belonging to the municipality of Ixmiquilpan diagnosed in Valle de Mezquital Regional Hospital in the first semester of 2017, with congenital syndrome associated with Zika + anencephaly, the first was in Mortinato and 
the second in the Huejutla region diagnosed in the Huasteca Regional Hospital with congenital syndrome associated with Zika + Microcephaly and reporting the patient's state alive. ${ }^{10}$

In the presence of the current Zika disease and given the epidemiological figures recorded in Mexico, we consider correct decision -making important in pregnant women due to neurological complications and the negative impact it has on the maternal-perinatal program that also has negative repercussions in the economic, social and health rubrics.

To describe the presence of neurological complications presented due to the Zika virus infection in pregnant women and their impact on maternal-perinatal decision-making.

\section{Methodology}

A systematic search was carried out regarding the epidemiological situation of Zika in the endemic population of Hidalgo state. The following were used as instruments for the study: articles from diverse populations, articles related to knowledge about the disease and epidemiological data to determine the coverage and control of the aforementioned disease. The data found were analyzed and evaluated to determine the coverage and scope of public health policies.

\section{DISCUSSION}

Since the Zika virus entered the Americas and its recent association with microcephaly among other malformations, it has caused the medical-scientific community to urgently have a very important interest in this specific group (pregnant women) which is at a higher risk and despite the little knowledge that we have about this disease, we continue to investigate and move forward establishing surveillance systems for this disease.

The congenital Zika virus syndrome consists of a series of fetal malformations, predominantly during the first 12 weeks of pregnancy, ${ }^{11}$ of which are related to specific brain lesions, calcifications (especially in the periventricular region, but also in the basal ganglia and in the brain parenchyma), ventriculomegaly, neuronal migration disorders, cerebellar hypoplasia and white matter abnormalities of the central nervous system, which share a pattern of cerebral atrophy and disorders in neuronal migration, which are the most striking and most severe. $^{8}$

Microcephaly is a nonspecific term that refers to the presence of a smaller head circumference than expected for a certain age. There are many causes of microcephaly, the most common are infections (cytomegalovirus, toxoplasma, rubella), genetic abnormalities and syndromes, teratogens (alcohol, radiation, exposure to heavy metals) and intrauterine growth restriction. ${ }^{12}$ Laboratory diagnosis is quite complicated due to the low specificity of immunological tests against other flaviviruses and the narrow window in which viral RNA can be detected in blood and other fluids after the onset of symptoms.,11,12 Ultrasound is currently considered as the only means to evaluate possible fetal compromises, so routine ultrasound controls of maximum importance for the detection of suspicious cases should be considered, ultrasonography fulfills the most important role in the screening of brain injuries in the fetuses of pregnant women exposed to the Zika virus infection, so the importance of establishing a systematic evaluation in routine ultrasound controls of pregnant women in the areas of transmission of the disease is evident. ${ }^{12}$

Likewise, it is important to highlight that fetal neurosonography is the reference standard in the evaluation of fetal brain anatomy and should be part of the diagnostic algorithm in all suspicious cases. ${ }^{12}$

The long-term consequences of microcephaly depend on the underlying brain abnormalities and can range from mild developmental delays to severe motor and intellectual deficits, such as cerebral palsy.

\section{Main consequences ${ }^{13}$}

- Convulsions.

- Delay in development, such as speech problems and other developmental indicators

- Intellectual disability

- Problems with movement and balance.

- feeding problems, such as difficulty swallowing.

- Hearing loss.

-vision problems

Severe microcephaly can also be life- 
threatening. Because it is difficult to predict, at birth, the problems that the baby with microcephaly will have, these babies will often need a health care provider to closely monitor them through regular check-ups to monitor their growth and development.10 Babies with more severe microcephaly will need attention and treatments focused on the control and management of their other health problems. Early development care services often help babies with microcephaly improve and maximize their physical and intellectual abilities. These services, known as early intervention, may include speech, occupational, and physical therapies. Sometimes medications are also needed to treat seizures and other symptoms. ${ }^{12,13}$

At this point is where the evaluation regarding the quality of life in patients with microcephaly is severely diminished, since in the aforementioned diagnostic evaluations it can be attributed to a reliable and timely diagnosis after 12 weeks of gestation which is the deadline period in which, if a woman desires it, the legal interruption of pregnancy is carried out. However, as we already know, talking about abortion is a paradox with a whole debate included, where an issue "exclusively" of women is discussed, which directly concerns their bodies and their rights, it is they who suffer the consequences and they assume the emotional, physical, social, economic and legal costs of an unplanned child and the practice of abortion, they are also the ones who assume the risks to their health and their lives.

\section{CONCLUSIONS}

Current evidence has shown that there is an association between the Zika virus infection with the presence of microcephaly and other congenital syndromes when it is transmitted vertically from the mother to the fetus, particularly during the first trimester of pregnancy, because of this determining the mechanisms of Zika virus emergence is fundamental to predict their course, also health decisions regarding this issue denote work in the interventions for the control of the vector, but also, monitoring of cases with microcephaly in terms of the treatment required monitoring closely the neurobiological development and the complications and impact occurring as part of the affectation by the virus to the brain tissue. Under this condition, the results regarding the state of health of the microcephaly case could lead to a better quality of life, otherwise the results will not have a positive impact.

Education is one of the alternatives to avoid contact between the vector and the human host, this means that not only in Mexico, but also throughout the world the educational model that is required is based on the constructivist approach to learning , promoting health from the traditional model of education will continue to yield negative results and increase the incidence of cases of microcephaly associated with Zika Virus. Another alternative that undoubtedly requires a high level of research is the development of a vaccine against Zika, since the clinical benefit would be reflected, above all, in the female population of reproductive age.

\section{ACKNOWLEDGEMENTS}

The authors of the present research article would like to acknowledge and thank the collaboration of truly Yesenia Ruvalcaba Cobián Elizabeth who has a BA in Teaching as a Foreign Language Ingles, for her Contributions on the review and translation of the article.

\section{CONFLICT OF INTERESTS}

The authors declare that there is no conflict of interest.

\section{REFERENCES}

1. Etymologia: Zika Virus. Emerg Infect Dis. 2014, 20(6): 1090.

2. Rodríguez, R. G. Enfermedad viral Zika. Revista Cubana de Medicina General Integral. 2016, 35(3).

3. Vorou Rengina. Zika virus, vectors, reservoirs, amplifying hosts, and their potential to spread worldwide: what we know and what we should investigate urgently. Internal J Infect Dis. 2016, 48:85-90.

4. Zanluca C, de Melo VCA, Mosimann ALP, dos Santos GIV, dos Santos CND, Luz K. First report of autochthonous transmission of Zika virus in Brazil. Mem Inst Oswaldo Cruz. 2015, 110:569-72

5. Vanlandingham DL, Higgs S, Huang YS. Aedes albopictus (Diptera: Culicidae) and MosquitoBorn Viruses in the United States. J Med Entomol. 2016, 53(5):989-991

6. Pacheco, E., Norambuena, G., Olivares, C., Luppi, N., \& Gaete, G. Virus Zika: epidemiología, 
manifestaciones clínicas y prevención. Rev. Hosp. Clin. Univ. Chile. 2015; 26(4), 277-284

7. Bin Cao, Meghal N ShetH, Indira U Mysorekar, To Zika and destroy: an antimalarial drug protects fetuses from Zika infection, Future Microbiology. 2018, Vol 13(2): 137-139

8. Albinagorta Olórtegui, R., \& Díaz-Vela, M. D. P. (2017). Salud fetal y diagnóstico ultrasonográfico en la infección perinatal por el virus zika. Revista Peruana de Ginecología y Obstetricia, 63(1), 7179.

9. SINAVE/DGE/SS: Sistema de Vigilancia Epidemiológica de Enfermedad por virus del Zika. 2018.

10. Dirección General de Epidemiología. Lineamientos Estandarizados para la Vigilancia Epidemiológica y Diagnóstico por Laboratorio de Infección por Virus Zika. México: Secretaria de
Salud. 2016.

11. OMS/OPS. Consideraciones provisionales para la atención de mujeres gestantes en escenarios con alta circulación del virus Zika: documento destinado a profesionales de salud. May 2nd 2016. Available at: file:///D:/Datos_ Perfil/570562/Downloads/ZIKAEmbarazo.pdf.

12. Cdc.gov. Datos sobre la microcefalia| Defectos de nacimiento | NCBDDD | CDC. 2018. [online] Available at: https://www.cdc.gov/ncbddd/ spanish/birthdefects/microcephaly.html [Consultado 20 Abr. 2018].

13. Ceped.org. Situación legal del aborto en las entidades de la República Mexicana, 2003. [online] Available at: http://www.ceped.org/ cdrom/avortement_ameriquelatine_2006/sp/ chapitre1-encadre3.html [Accessed $26 \mathrm{Abr}$. 2018]. 